Yol.2 2Nn. I لanuari 2019

ISSN 2614-2775

e-ISSN 2621-8143

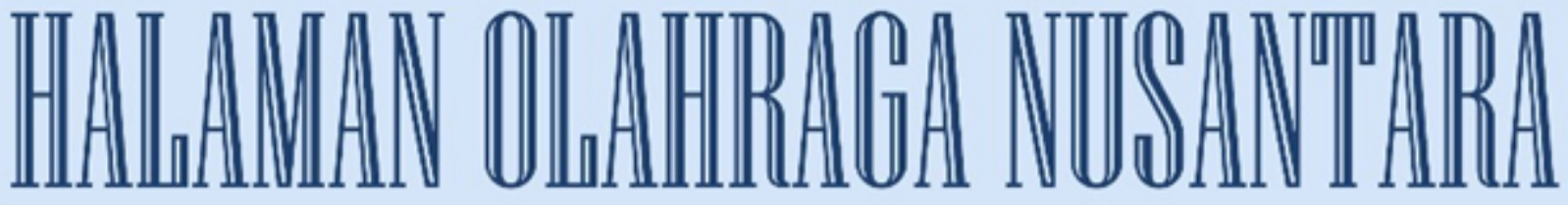

Surnal @lmu Xeolahragaan

Diterbitkan Oleh:

Program Studi Pendidikan Olahraga

Fakultas Keguruan dan Ilmu Pendidikan

Universitas PGRI Palembang

Jurnal

Volume Nomor Halaman Palembang ISSN/e-ISSN

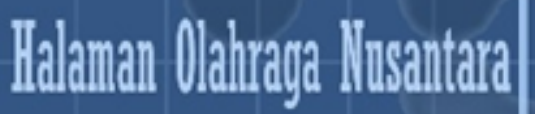

\begin{tabular}{l|l|l|l}
2 & 1 & $1-96$ & 2019
\end{tabular}




\section{Halaman Olahraga Nusantara}

Jurnal Ilmu Keolahragaan

Volume 2, Nomor 1, Januari 2019

Pelindung/Penasehat

Dr. H. Bukman Lian, M. M., M. Si.

Penanggung Jawab

Dr. Dessy Wardiah, M. Pd.

Ketua Dewan Redaksi

Farizal Imansyah, M. Pd.

Wakil Ketua Dewan Redaksi

Ilham Arvan Junaidi, M. Pd.

Sekretaris

Bayu Iswana, M. Pd.

Penyunting Pelaksana

Rafel Orlando, M. Pd.

Ardo Okilanda, M. Pd.

Daryono, M. Pd.

\section{Mitra Bestari}

Prof. Dr. A. Sofyan Hanif, M. Pd (Universitas Negeri Jakarta)

Dr. Sukirno (Universitas Sriwijaya)

Dr. Ronni Yenes, M. Pd (Universitas Negeri Padang)

Dr. Benny, M. Pd. (Universitas Negeri Makasar)

Dr. Putri Cicilia Kristina, M. Pd (Universitas PGRI Palembang)

\section{Tata Usaha}

M. Taheri Akbar, M. Pd.

Widya Handayani, S. Pd., M. Si.

Setting:

Dede Dwiansyah Putra, M. Pd.

Alamat Redaksi:

Prodi Pendidkan Olahraga Fakultas Keguruan Ilmu dan Pendidikan Universitas PGRI Palembang

Jl. Jendral A. Yani Lorong Gotong Royong 9/10 Ulu Palembang

Telp. 0711-510043, Fax. 0711-514782

e-mail jurnal: jurnalhonupgripalembang@gmail.com

e-mail : ardo.oku@univpgri-palembang.ac.id

website: univpgri-palembang.ac.id 
Halaman Olahraga Nusantara (Jurnal Ilmu Keolahragaan)

P-ISSN 2614-2775

Volume 2, No. 1, Januari 2019

E-ISSN 2621-8143

\section{DAFTAR ISI}

Hasil Penelitian

Halaman

Pengaruh Metode Rangkaian Bermain Terhadap Keterampilan Dasar Olahraga Panahan Siswa Ektrakulikuler Sit (Sekolah Islam Terpadu) Auladi Palembang

- Arisman

Penerapan Metode Bermain Dalam Meningkatkan Hasil Belajar Guling Depan (Forward Roll)

- Ruslan, M. Samsul Huda

Survei Tingkat Kesegaran Jasmani pada Peserta Ekstrakulikuler Sepakbola Di Sma Negeri 2 Oku

- Daryono

Kontribusi Daya Ledak Tungkai dan Keseimbangan Terhadap Kemampuan Lompat Jauh Murid Sd Negeri 139 Sinjai

- Adam Mappaompo

Survei Tingkat Kebugaran Jasmani Mahasiswa Pendidikan Olahraga Angkatan 2017 Stkip Pgri Bangkalan

- Heni Yuli Handayani .

Profil Delayed Onset Muscle Soreness (Doms) pada Mahasiswa Fik Unp Setelah Latihan Fisik

- Heru Syarli Lesmana

Perbedaan Pengaruh Latihan Menggunakan Karet dengan Menggunakan Dumbbell $1 \mathrm{Kg}$ Terhadap Kecepatan Pukulan Oi Tsuki

Chudan pada Atlet Karate Putra Perguruan Wadokai Dojo Sma Negeri 11 Medan Tahun 2017

- Pangondian Hotliber Purba $60-71$

Tinjauan Kondisi Fisik Atlet Sepakbola Kabupaten Kerinci Dalam

Rangka Persiapan Mengikuti Porprov Xxii Bungo Tebo 2018

- Palmizal, Wawan Junresti Daya, dan Sri Murniati

Aktivitas Jasmani dan Persepsi Gerak Anak Usia Dini

- Dian Pujianto 
Peningkatan Keterampilan Bermain Bolabasket Mahasiswa Melalui Latihan Aktifitas Maze Perkuliahan Permainan Bolabasket

- Ilham Arvan Junaidi dan Rury Rizhardy $88-96$ 


\title{
PENERAPAN METODE BERMAIN DALAM MENINGKATKAN HASIL BELAJAR GULING DEPAN (FORWARD ROLL)
}

\author{
Ruslan, M. Samsul Huda \\ (Dosen FKIP Universitas Mulawarman)
}

\begin{abstract}
Abstrak
Tujuan penelitian untuk mengetahui apakah penerapan metode bermain dapat meningkatkan hasil belajar guling depan. Manfaat penelitian ini adalah untuk memberikan gambaran para pendidik tentang penggunaan penerapan metode bermain yang sesuai dalam kegiatan proses belajar mengajar, sehingga dapat meningkatkan kualitas hasil pembelajaran. Jenis penelitian yang digunakan dalam penelitian ini adalah penelitian tindakan dan dilaksanakan dua siklus, setiap siklus dimulai dengan perencanaan, tindakan, observasi, dan refleksi. Subjek penelitian ini adalah siswa SD 011 Samarinda kelas $3 a$ berjumlah 40 siswa. Data dikumpulkan dari hasil observasi dan hasil tes belajar guling depan. Hasil penelitian ini menunjukkan bahwa terjadi peningkatan hasil belajar siswa, terbukti pada data siklus 1 siswa yang berhasil 18 siswa (45\%) dan siswa yang tidak berhasil 22 siswa (55\%). Pada siklus II terlihat peningkatan yang signifikan bahwa siswa yang tuntas berjumlah 35 siswa (87,5\%) dan yang tidak tuntas 5 siswa (12,5\%). Selain itu, dengan metode bermain dapat meningkatkan keaktifan siswa pada pembelajaran guling depan. Dengan demikian dapat disimpulkan bahwa penerapan metode bermain efektif untuk meningkatkan hasil belajar siswa dalam pembelajaran guling depan pada siswa SD kelas $3 a 011$ Samarinda. Kepada guru untuk dapat menerapkan hasil penelitian ini secara berkesinambungan agar dapat menerapkan metode bermain ini sebagai alternatif dalam proses pembelajaran sebagai upaya meningkatkan hasil belajar siswa khususnya guling kedepan.
\end{abstract}

Kata Kunci : Penerapan Metode Bermain, Hasil Belajar Guling Depan

\section{APPLICATION OF PLAYING METHODS IN IMPROVING FRONT LEARNING OUTCOMES FORWARD ROLL}

\begin{abstract}
The aim of the research is to find out whether the application of the playing method can improve learning outcomes in front roll. The benefit of this study is to give educators an overview of the use of appropriate methods of play in the activities of the teaching and learning process, so as to improve the quality of learning outcomes. The type of research used in this study is action research and carried out two cycles, each cycle begins with planning, action, observation, and reflection. The subjects of this study were SD 011 Samarinda students in grade 3 a totaling 40 students. Data was collected from the results of observations and the results of learning tests rolled forward. The results of this study indicate
\end{abstract}


that there is an increase in student learning outcomes, as evidenced in the data of cycle 1 students who succeed 18 students (45\%) and students who do not succeed 22 students (55\%). In cycle 2, there was a significant increase in students who completed 35 students (87.5\%) and those who did not complete 5 students (12.5\%). In addition, the playing method can increase student activity in front roll learning. Thus it can be concluded that the application of playing methods is effective to improve student learning outcomes in front roll learning in elementary school students grade 3 a 011 Samarinda. To the teacher to be able to apply the results of this study on an ongoing basis in order to apply this method of play as an alternative in the learning process as an effort to improve student learning outcomes, especially rolling ahead.

Keywords: Application of Play Methods, Learning Results of roll forward

\section{A. PENDAHULUAN}

Proses pembelajaran yang baik tentunya hasil dari pada proses pembelajaran tersebut haruslah diutamakan. Tidak hanya itu, ketrampilan individu khususnya dalam pendidikan jasmani juga harus diperhatikan karena hal tersebut juga dapat sebagai dasar keberhasilan dari pembelajaran. Menurut (James Tangkudung, 2012:12) "perkembangan anak pada hakekatnya tergantung dari usaha anak tersebut dalam mengembangkan dirinya" Untuk mencapai hal tersebut Guru memegang peranan yang sangat penting dan pada hakekatnya seorang pendidik harus menyadari juga akan tugas dan tanggung jawabnya dalam membantu perkembangan anak. Oleh karena itu, seorang guru selalu dituntut untuk lebih mengembangkan kreatifitas maupun melakukan inovasi dalam rangka pencapaian tujuan pembelajaran tersebut. Kemampuan guru dalam mengembangkan pembelajaran selain bertujuan untuk meningkatkan keberhasilan pencapaian tujuan belajar dan meningkatkan aktivitas gerak siswa. Guru juga dituntut dapat menciptakan suasana yang lebih menarik sehingga menumbuhkan motivasi pada diri siswa.

Guling depan merupakan salah satu materi senam yang penguasaan rangkaian keterampilan geraknya dilakukan secara berurutan. Keterampilan gerak yang dimaksud meliputi sikap awalan jongkok yang seimbang dengan posisi berhadapan arah gerakan, kedua telapak tangan di samping telinga menghadap ke bawah. Inti dari gerakan guling depan terletak pada tolakan kaki dan sikap badan 
ke depan. Namun, bagi siswa yang tidak memiliki keberanian dan tolakan tangan dan tumpuan kaki yang kuat serta penguasaan keterampilan guling depan yang kurang, tentunya akan mengalami kesulitan dalam melakukan gerakan tersebut. Hal ini jelas dikarenakan tangan kurang kuat dan tolakan kaki dalam menolak sehingga menimbulkan gerakan yang salah. Disamping itu pemberian materi yang terlalu singkat dan kurangnya pendekatan kepada siswa lebih menjadikan siswa umum kesulitan dalam melakukan gerakan guling depan dengan baik dan benar, sehingga sasaran dari pembelajaran tersebut tidak tercapai.

Pembelajaran senam lantai khususnya guling depan masih banyak ditemui masalah dalam pelaksanaannya, pelaksanaan pembelajaran senam lantai khususnya guling depan kurang maksimal. Kurang kreatifnya guru, pendekatan yang kurang dan penggunaan metode yang masih biasa menjadi salah satu dasar masalah yang ingin dipecahkan. Berdasarkan Uraian diatas terdapat beberapa masalah yang harus segera terpecahkan agar tujuan pembelajaran tercapai. Menindaklanjuti hal tersebut, maka peneliti memberikan pendekatan bermain dengan menggunakan beberapa jenis permainan dalam proses pembelajaran sebagai upaya untuk peningkatkan hasil belajar senam lantai guling depan yang lebih efektif dan baik.

\section{B. METODE PENELITIAN}

Penelitian ini merupakan penelitian tindakan (Action Research). Penelitian tindakan adalah cara suatu kelompok dalam mengorganisasi suatu kondisi, di mana mereka, dapat mempelajari pengalaman mereka, dan membuat pengalaman mereka dapat diakses oleh orang lain. Bentuk penelitian tindakan dipilih atas dasar pemikiran bahwa guru sekolah dasar adalah pelaksana pendidikan yang mampu mengidentifikasi permasalahan pembelajaran namun memiliki keterbatasan kemampuan dalam menyelesaikan masalah khususnya berkaitan dengan pembelajaran senam lantai. Untuk itu, peneliti bermaksud melakukan penelitian tindakan yang bekerjasama dengan guru pelaksana, guru kolaborasi, dan guru mata pelajaran untuk meningkatkan hasil belajar senam lantai (materi guling depan). 
Obyek dalam penelitian ini adalah penerapan metode bermain pada pembelajaran senam lantai guling depan. Penelitian ini menggunakan penelitian tindakan menurut Kemmis dan Taggart yang terdiri dari empat tahap yaitu: Perencanaan, Tindakan, Pengamatan, dan Refleksi. Teknik pengumpulan data menggunakan tes keterampilan guling depan untuk data kuantitatif peningkatan hasil belajar dan menggunakan observasi, catatan lapangan, dokumentasi untuk data kualitatif.

\section{HASIL DAN PEMBAHASAN}

Deskripsi data hasil penelitian, merupakan gambaran umum karakteristik pelajaran senam (guling depan) yang menjadi subjek penelitian ini. Keterampilan senam (guling depan) yang terdiri dari beberapah tahapan gerakan: berdiri tegap dan kedua tangan diangkat lurus ke atas membentuk "V" lalu pandangan lurus kedepan, kemudian diikuti dengan menekuk kedua lutut hingga agak jongkok atau setengan jongkok dan tangan lurus kedepan, lalu gulingkan badan kebelakang dengan tangan siap menyanggah dan memberi dorongan agar mendapat gulingan yang maksimal, pada saat berguling kaki lurus dan saat menjatuhkan kaki dijatuhkan jauh di atas kepala, lalu kembali keposisi semula yakni berdiri tegak dengan pandangan mata ke arah depan. melalui metode bermain yang dimana dilakukan tes awal sebagai tolak ukur keberhasilan siswa sebelum penelitian tindakan dilakukan.

Berdasarkan tujuan penelitian yang telah dirumuskan, penggunakan pendekatan metode bermain dalam meningkatkan pelajaran senam (guling depan) siswa. Melalui penelitian ini ingin diketahui sejauh mana dampak penggunaan metode bermain dalam meningkatkan pelajaran senam (guling depan) siswa. Gambaran kemampuan pelajaran senam (guling depan) siswa sebelum dan sesudah diberikan perlakuan dapat dilihat pada statistik deskriptif skor prasiklus dan skor siklus 1 dalam bentuk tabel.

Hasil prasiklus terlihat bahwa skor yang diperoleh interpretasi datanya sebagai berikut : siswa yang mempunyai skor 50-59 sebanyak 6 siswa atau 15 $\%$, siswa yang mempunyai skor 60 - 69 sebanyak 26 siswa atau $65 \%$, siswa 
yang mempunyai skor 70 - 79 sebanyak 6 siswa atau $15 \%$, siswa yang memperoleh skor 80 - 89 sebanyak 2 siswa atau $5 \%$, dan siswa yang memperoleh skor 90 - 100 sebanyak 0 siswa atau $0 \%$. Dari data di atas terlihat bahwa data awal masih jauh dari nilai maksimal yang telah di tentukan. Dengan melihat hasil deskripsi di atas dari perolehan nilai pelajaran senam (guling depan) siswa dan peningkatannya dapat disajikan dalam bentuk Grafik batang di bawah ini.

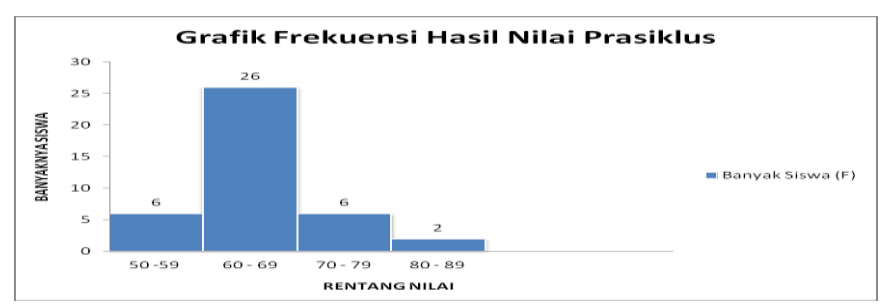

\section{Grafik 1}

Grafik Diagram Batang Perolehan nilai tes pelajaran senam (guling depan) siswa Pra Siklus (Data Awal)

Dengan melihat hasil tes pada prasiklus diatas sebelum mencapai perolehan nilai yang signifikan atau sesuai dengan tujuan penelitian, maka dilaksanakan kegiatan meteode bermain siklus 1 .

Berdasarkan tujuan penelitian yang telah dirumuskan, penggunakan pendekatan bermain merupakan upaya yang ditempuh dalam meningkatkan kemampuan senam (guling depan) siswa. Melalui penelitian ini ingin diketahui sejauh mana pengaruh penggunaan pendekatan bermain dalam meningkatkan kemampuan senam (guling depan) siswa. Gambaran kemampuan senam (guling depan) siswa sebelum dan sesudah diberikan perlauan dapat dilihat pada statistik deskriptif skor prasiklus dan skor siklus 1 dalam bentuk tabel.

Dari hasil siklus 1 terlihat bahwa skor yang diperoleh interpretasi datanya sebagai berikut : siswa yang mempunyai skor 60 - 69 sebanyak 22 siswa atau 55 $\%$, siswa yang mempunyai skor 70 - 79 sebanyak 14 siswa atau $35 \%$, siswa yang memperoleh skor 80 - 89 sebanyak 4 siswa atau $10 \%$, dan siswa yang memperoleh skor 90 - 100 sebanyak 0 siswa atau $0 \%$. Dari data di atas terlihat bahwa data awal masih jauh dari nilai maksimal yang telah di tentukan, maka akan dilakukan ke siklus berikutnya. Dengan melihat hasil deskripsi di atas dari 
perolehan nilai tes senam (guling depan) dan peningkatannya dapat disajikan dalam bentuk Grafik batang di bawah ini.

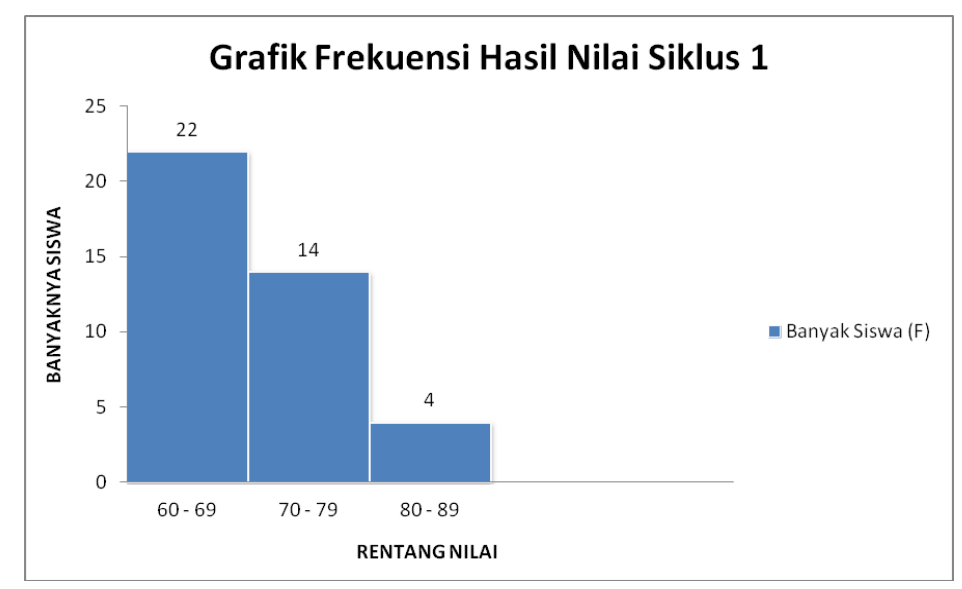

\section{Grafik 2 \\ Grafik diagram Batang Perolehan nilai tes senam (guling depan) Siklus 1}

Dengan melihat hasil tes pada prasiklus diatas sebelum mencapai perolehan nilai yang signifikan atau sesuai dengan tujuan penelitian, maka dilaksanakan kegiatan metode bermain siklus 2 .

Dari hasil siklus 2 terlihat bahwa skor yang diperoleh interpretasi datanya sebagai berikut : siswa yang mempunyai skor 60 - 69 sebanyak 5 siswa atau 12,5 $\%$, siswa yang mempunyai skor 70 - 79 sebanyak 24 siswa atau $60 \%$, siswa yang memperoleh skor 80 - 89 sebanyak 11 siswa atau 27,5\%, dan siswa yang memperoleh skor 90 - 100 sebanyak 0 siswa $0 \%$.

Dari data di atas terlihat bahwa nilai yang diperoleh pada siklus 1 lebih baik dari nilai yang diperoleh pada data awal, tetapi nilai pada siklus 2 sudah mencapai targert penelitian (siswa yang telah mencapai nilai 70.0 keatas sebanyak 35 siswa atau 87,5\%). Sesuai dengan kriteria keberhasilan penelitian maka penelitian sudah berhasil pada siklus 2 dan tentunya tidak dilanjutkan pada siklus berikutnya.

Dengan melihat hasil deskripsi di atas perolehan nilai tes senam (guling depan) dan peningkatannya dapat disajikan dalam bentuk grafik diagram batang di bawah ini. 


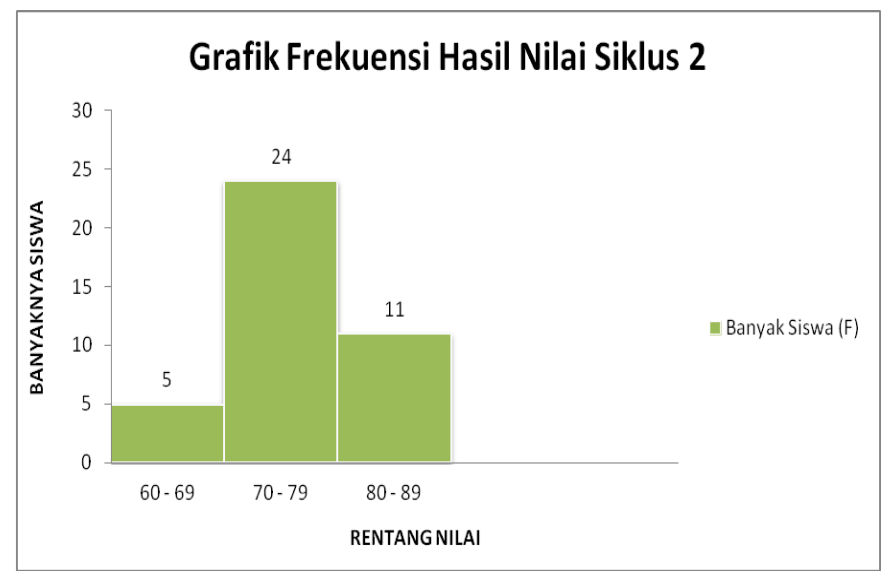

\section{Grafik 3}

Grafik Diagram Batang Perolehan Nilai Tes senam (guling depan) Siklus 2

Dengan melihat hasil tes senam (guling depan) dengan metode bermain dari prasiklus dan siklus 1 didapat perbandingan sebagai berikut :

\section{Tabel 8}

Peningkatan Sebelum Diberikan Tindakan (Prasiklus) dan Siklus 1

\begin{tabular}{ccccccc}
\hline \multirow{2}{*}{ No } & \multirow{2}{*}{ Katagori } & \multirow{2}{*}{ Nilai } & \multicolumn{2}{c}{ Pra Skilus } & \multicolumn{2}{c}{ Siklus 1 } \\
\cline { 3 - 7 } & & $\mathrm{F}$ & $\%$ & $\mathrm{~F}$ & $\%$ \\
\hline 1 & Tuntas & $\geq 70$ & 8 & 20 & 18 & 45 \\
\hline 2 & Tidak tuntas & $\leq 69$ & 32 & 80 & 22 & 55 \\
\hline & Jumlah & & 40 & 100 & 40 & 100 \\
\hline
\end{tabular}

Dari hasil perhitungan data di atas diperoleh analisa peningkatan hasil senam (guling depan) sebelum diberikan metode bermain dan sesudah diberikan metode bermain pada siklus 1 adalah sebagai berikut : peningkatan sebanyak 18 siswa yang berhasil atau $45 \%$ dari jumlah keseluruhan siswa yang menunjukan kemajuan dan peningkatan senam (guling depan) dari tes awal (pra siklus) ke siklus 1.

Dilihat dari tabel diatas dapat disimpulkan bahwa pada data awal siswa yang berhasil 8 siswa (20\%) dan siswa yang tidak berhasil 32 siswa (80\%). Pada siklus 1 terlihat peningkatan yang signifikan bahwa siswa yang berhasil berjumlah 18 siswa (45\%) dan yang tidak berhasil 22 siswa (55\%), jadi dapat 
disimpulkan bahwa ada peningkatan dari hasil metode bermain yang dilihat dari data awal dibandingkan dengan siklus 1 .

\section{Diagram Batang Perbandingan Pra Siklus dengan Siklus 1}

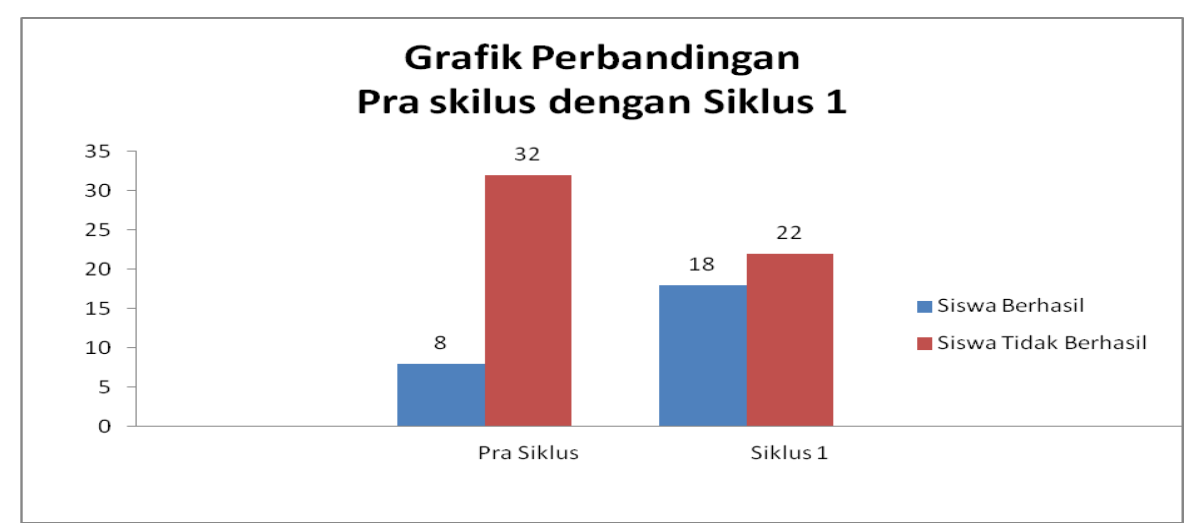

\section{Peningkatan Nilai dari Siklus 1 ke Siklus 2}

Dengan melihat hasil tes senam (guling depan) dengan metode bermain dari siklus 1 dan siklus 2 didapat perbandingan sebagai berikut :

Tabel 4

Peningkatan Siklus 1 ke siklus 2

\begin{tabular}{ccccccc}
\hline \multirow{2}{*}{ No } & \multirow{2}{*}{ Katagori } & \multirow{2}{*}{ Nilai } & \multicolumn{2}{c}{ Skilus 1 } & \multicolumn{2}{c}{ Siklus 2 } \\
\cline { 3 - 7 } & & $\mathrm{F}$ & $\%$ & $\mathrm{~F}$ & $\%$ \\
\hline 1 & Tuntas & $\geq 70$ & 18 & 45 & 35 & 87,5 \\
\hline 2 & Tidak tuntas & $\leq 69$ & 22 & 55 & 5 & 12,5 \\
\hline & Jumlah & & 40 & 100 & 40 & 100 \\
\hline
\end{tabular}

Dari hasil perhitungan data di atas diperoleh analisa peningkatan senam (guling depan)setelah diberikan metode bermain pada siklus 1 ke siklus 2 adalah sebagai berikut : peningkatan sebanyak 35 siswa yang tuntas atau 87,5\% dan 5 siswa yang tidak tuntas atau $12,5 \%$ dari jumlah keseluruhan siswa yang menunjukan kemajuan dan peningkatan senam (guling depan).

Dilihat dari tabel diatas dapat disimpulkan bahwa pada data siklus 1 siswa yang tuntas 18 siswa (45\%) dan siswa yang tidak tuntas 22 siswa (55\%). Pada siklus 2 terlihat peningkatan yang signifikan bahwa siswa yang tuntas berjumlah 35 siswa $(87,5 \%)$ dan yang tidak tuntas 5 siswa (12,5\%), jadi dapat disimpulkan bahwa ada peningkatan dari hasil metode bermain yang dilihat dari data siklus 1 
dibandingkan dengan siklus 2. Peneliti dan kolaborator telah menemukan jawaban yang menjadi bahan penelitian, yaitu metode bermain dapat meningkatkan pembelajaran senam (guling depan).

\section{Diagram Batang Perbandingan Siklus 1 dengan Siklus 2}

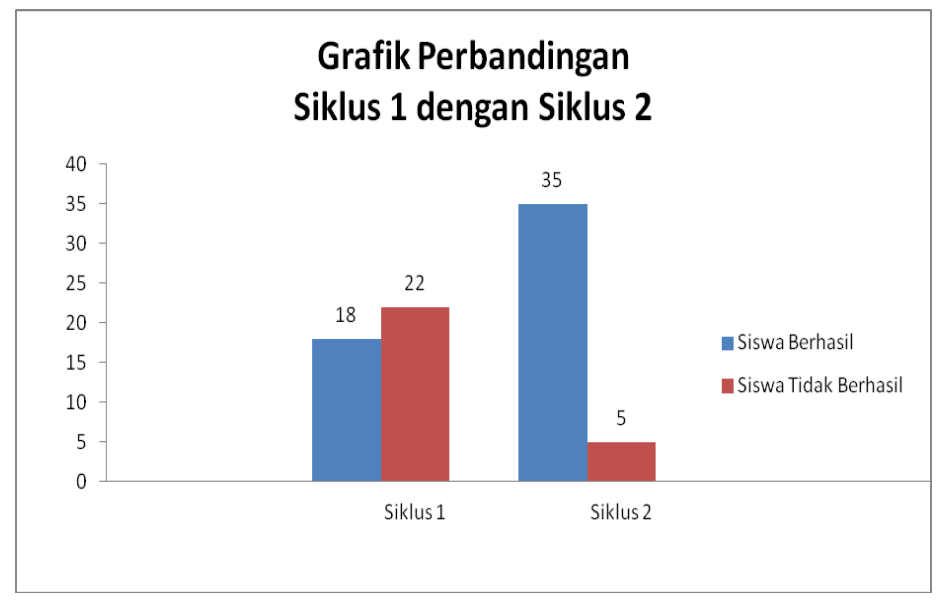

Metode bermain dalam pembelajaran guling depan merupakan alternatif dalam memecahkan beberapa masalah yang dihadapi guru dalam upaya mengaktifkan siswa dalam belajar karena guru penjasorkes berperan sebagai pemimpin siswa, manajer yang mengelola kegiatan belajar dan mengajar, fasilitator yang berupaya menciptakan lingkungan belajar yang mengefektifkan proses belajar siswa.

Dalam setiap model permainan dalam metode ini, guru harus mampu menciptakan kelas yang konduksif agar hubungan interaktif siswa dengan guru ataupun siswa dengan siswa, sehingga dapat terwujud sehingga suasana kelas menjadi aktif dan menarik. Dalam hal ini guru harus mampu menjadi contoh dan teladan siswanya. Dengan penerapan metode bermain ini para siswa lebih bisa terlatih untuk mempelajari seseuatu dengan suasana yang berbeda, lebih termotivasi dan harus lebih serius, karena guru dan siswa sudah menyepakati aturan-aturan yang dibuat bersama sebelum pelajaran dimulai. Karena kalau tidak sungguh-sungguh dalam mengikuti pelajaran dan melakukan pelanggaran akan mendapat hukuman. Dengan demikian maka masalah dan tujuan dari pada penelitian ini terjawab berdasarkan hasil penelitian yang di dapat melalui 
penerapan metode bermain dapat membantu dalam pembelajaran senam lantai khususnya guling depan memberikan dampak yang positif bagi siswa.Dalam proses pembelajaran senam lantai, contoh kebaharuan dalam penelitian ini adalah Ashandika, Doni and Sugihartono, Tono and Pujianto, Dian yang berjudul Penerapan media bantu untuk meningkatkan keterampilan guling kedepan senam lantai. Namun dalam penelitian ini menggunakan metode bermaindalam membantuh ditumbuh kembangkan dan terapkan kepada siswa guna meningkatkan keterampilan siswa disamping dapat meningkatkan daya tarik belajar siswa sehingga dalam pembelajaran senam lantai siswa tidak terlalu cepat bosan. Sistim pembelajaran ini mengacu pada kurikulum yang dirancang dan dilaksanakan sesuai dengan kebutuhan siswa baik fisik maupun mental.

\section{KESIMPULAN}

Berdasarkan hasil penelitian dan pembahasan, dapat disimpulkan sebagai berikut : Pembelajaran dengan penerapan metode bermain dalam pembelajaran senam guling depan pada siswa kelas 3a SD Negeri 011 Samarinda mempunyai peningkatan hasil belajar, yaitu persentase ketuntasan hasil belajar guling depan pada siklus I adalah 18 siswa (45\%) dan siswa yang tidak tuntas 22 siswa (55\%)dan untuk siklus II sebesar terlihat peningkatan yang signifikan bahwa siswa yang tuntas berjumlah 35 siswa $(87,5 \%)$ dan yang tidak tuntas 5 siswa $(12,5 \%)$ yang artinya dengan penerapan metode bermain dapat meningkatkan hasil belajar guling depan. Penerapan metode bermain ternyata efektif dalam proses pembelajaran senam guling depan yang dikemas dalam bentuk permainan. Selain itu metode ini dapat bermanfaat dalam menimbulkan suasana pembelajaran yang lebih baik, karena siswa merasa senang dan gembira dalam menerima dan mengikuti pembelajaran senam guling depan.

\section{DAFTAR PUSTAKA}

Ashandika, Doni dan Sugihartono, Tono dan Pujianto. 2014. Penerapan media bantu untuk meningkatkan keterampilan guling kedepan senam lantai. http;//repository.unib.ac.id/id/eprint/9030. 
Aunurrahman. 2010. Belajar dan Pembelajaran. Bandung: Alfabeta.

Departemen Pendidikan Dan Kebudayaan Direktorat Jenderal Pendidikan Tinggi Proyek pembinaan Tenaga Kependidikan. Jakarta. 1992.

Emzir. 2012. Metodologi Penelitian Pendidikan. Jakarta: Raja Grafindo Persada.

Isnaini, Farida dan Suranto. 2010. Pendidikan Jasmani, Olahraga dan Kesehatan untuk SMP/MTs. Jakarta: Pusat Perbukuan.

J Arm, Z. Bradac, R. Stohl. 2016. Increasing Safety and Realibility of Roll- back and Roll-Forward Lockstep Technique for Use in Real-time Systems. IFAC - Papers Online 49-25. 413-418.

Kemmis, Stephen Robin McTaggart and Rhonda Nixon. 2014. The Action Research Planner Doing Critical Participatory Action Research. Singapore: Springer.

Marsuki. 2017. Meningkatkan Pembelajaran Rool depan dengan alat bantu bola lonceng. e-jurnal mitra pendidikan, 58-67. 2550-0481.

Mita, Erliana. 2015. Peningkatan hasil belajar gerakan senam lantai guling kedepan dengan menggunakan media matras dan variasi pembelajaran. Http://eprints.ulm.ac.id./id/eprint/2936.

Micheal S. Owen, Madhu Vinjamur, LE. Scriven, C.W. Macosko. 2011. Misting of non-Newtonian Liquids in Forward rool Coating. Juornal of NonNewtonian Fluid Mechanics, 166. 1123-1128.

R.W. Hewson. N. Kapur. 2013. Effects of shear Thinning on forward rool coating. Chemmical Engineering Research and Design, 91. 2427-2436.

Suressh.K. Devisetti, Douglas W.Bousfield. Fluid Absorption during forward roll coating of porous webs. Chemical Engineering Science, 65, 3528-3537.

Sukardi, M. 2012. Metode Penelitian Pendidikan Tindakan. Yogyakarta: Bumi Aksara.

Satya, Wira Indra. 2006. Membangun Kebugaran Jasmani dan Kecerdasan Melalui Bermain. Jakarta: Departemen Pendidikan Nasional. 


\section{GAYA SELINGKUNG}

1. Jurnal Halaman Olahraga Nusantara menerbitkan karya ilmiah dan hasil penelitian dalam seluruh kajian ilmu keolahragaan, baik pendidikan, kepelatihan, dan lainya dalam pengembangan teori dan konsep yang belum pernah dipublikasikan. Jurnal ini memuat (1) kumpulan informasi baru, (2) hasil objektif dari suatu kajian ilmu keolahragaan, dan (3) rekomendasi.

2. Penulisan naskah menggunakan bahasa Indonesia secara benar. Panjang naskah antara 7-20 halaman, kertas ukuran quarto, diketik 1,5 spasi, tipe huruf Times New Roman, ukuran huruf 12, margin atas dan kiri 4 cm, kanan dan bawah $3 \mathrm{~cm}$.

3. Naskah ditulis dengan sistematika dan ketentuan sebagai berikut.

a. Judul: ditulis dengan singkat, padat, terdiri dari 5-15 kata, dan menggunakan bahasa Indonesia, harus mencerminkan substansi keilmuan yang diuraikan pada batang tubuh artikel. Judul utama (main title) dan anak judul (subtitle) dipisahkan dengan dua titik. Judul artikel dicetak 15 mm dibawah tepi atas, dengan huruf capital-kecil tebal. Judul subbab peringkat 1 dicetak capital semua, rata tepi kiri, tebal, peringkat 2 dicetak capital kecil, rata tepi kiri, tebal; peringkat 3 dicetak kapital-kecil, rata tepi kiri, miring-tebal.

b. Nama penulis: Nama penulis artikel ditulis tanpa disertai gelar akademik atau gelar apapun. Nama lengkap dengan gelar akademik boleh ditulis disebelah bawah halaman pertama artikel. Nama lembaga tempat bekerja penulis juga dibuat sebagai catatan kaki dihalaman pertama. Jika lebih dari tiga penulis, hanya penulis utama saja yang dicantumkan dibawah judul; nama penulis lain ditulis dalam catatan kaki.

c. Abstrak artikel kajian ilmiah/ konseptual adalah ringkasan dari isi artikel yang dituangkan secara padat menggunakan bahasa Indonesia dan bahasa inggris. Abstrak hasil penelitian memuat masalah atau tujuan, metode, dan hasil penelitian. Abstrak terdiri dari 100-300 kata yang disusun dalam satu 
paragraph dengan format esei bukan enumeratif, dan diketik dengan spasi tunggal serta dengan format yang lebih sempit dari teks utama.

d. Kata Kunci terdiri dari 3-5 kata, yaitu istilah-istilah yang mewakili ide atau konsep dasar yang dibahas dalam penulisan karya ilmiah. Kata kunci lazimnya berupa kata dasar atau kata yang berdiri sendiri (tunggal) bukan rangkaian kata.

e. Naskah hasil penulisan ditulis dengan urutan (1) judul, (2) nama penulis, (3) abstrak, (4) kata kunci, (5) bagian pendahuluan yang harus di akhiri dengan rumusan singkat (1-2 kalimat) tentang hal-hal pokok yang akan dibahas dan tujuan dari pembahasan. Untuk artikel hasil penelitian berisi (a) rumusan masalah, (b) tujuan, dan (c) deskripsi singkat mengenai kerangka pemikiran dalam pendahuluan, (6) isi memuat (a) metode penelitian, (b) hasil penelitian, dan (c) pembahasan. (8) simpulan dan saran, (9) daftar pustaka.

f. Naskah diluar hasil penelitian ditulis dengan urutan (1) judul, (2) nama penulis, (3) abstrak, (4) kata kunci, (5) pendahuluan yang memuat latar belakang dan rumusan masalah, (6) isi, (7) simpulan, dan (8) daftar pustaka.

g. Table dan gambar/ bagan di usahakan dicetak dalam satu halaman, nomor dan judul table dan gambar dicetak di atas table dengan huruf tebal. Isi dalam table dicetak dengan huruf normal (tidak tebal). Table hanya menggunakan garis horizontal (horizontal border)

h. Penulisan daftar pustaka

1) Buku ditulis dengan urutan: (a) nama akhir, (b) koma, (c) nama depan penulis, (d) titik, (e) tahun penerbitan, (f) titik, (g) judul buku dalam huruf miring, (h) titik, (i) edisi jika ada, (j) titik, (k) kota penerbitan, (l) titik dua, (m) nama penerbit, dan (n) titik.

2) Artikel ditulis dengan urutan: (a) nama akhir, (b) koma, (c) nama depan penulis, (d) titik, (e) tahun penerbitan, (f) titik, (g) tanda petik dua, (h) judul artikel, (i) titik, (j) tanda petik tutup, (k) nama jurnal dalam cetak miring, (l) volume, (m) nomor, dan (n) titik. Apabila artikel diterbitkan 
disuatu buku, tulis kata "dalam" sebelum nama editor buku tersebut, dan buku harus ditulis didalam daftar pustaka.

3) Skripsi, thesis, atau disertasi ditulis dengan urutan: (a) nama akhir, (b) koma, (c) nama depan penulis, (d) titik, (e) tahun, (f) titik, (g) judul dalam huruf miring, (h) skripsi/thesis/disertasi pada (nama perguruan tinggi yang bersangkutan), (i) nama kota, (j) titik dua, (k) tulisan "tidak diterbitkan", dan (1) titik. 